\title{
Composition and morphology of copper bismuth selenide layer on glass prepared by chemical conversion technique
}

\author{
Viktorija Osipovaitè, \\ Ingrida Ancutiené $\dot{~}^{*}$ \\ Department of Physical and \\ Inorganic Chemistry, \\ Kaunas University of Technology, \\ Radvilenu Rd. 19, \\ 50254 Kaunas, Lithuania
}

\begin{abstract}
A copper bismuth selenide layer prepared by the chemical conversion of a copper selenide layer on glass has been studied. SEM images display layers with a nonhomogeneous morphology. The copper selenide layer was non-uniform and consisted of dendrites and particulated agglomerates. The surface of the chemically converted layer was denser and smoother with closely spaced spherical grains. The EDX results reveal that the converted samples are rich in copper and poor in bismuth. The phases of copper selenides in the obtained layer and copper bismuth selenide and hexagonal selenium in the annealed converted layer were detected using the XRD analysis. Copper selenide peaks are most dominant with the hexagonal klockmannite phase.
\end{abstract}

Keywords: selenopolythionates, copper selenide, copper bismuth selenide, SEMEDX, XRD

\section{INTRODUCTION}

Due to extensive applications and future prospects, semiconducting chalcogenide films have received much attention in recent years. Thin films play a crucial role in the present day science and technology due to their wide use in a large number of active and passive devices [1]. Metal chalcogenide thin layers are of particular interest for the fabrication of large area photodiode arrays, solar selective coatings, solar cells, photoconductors, sensors, and so on [2]. Binary, ternary and quaternary chalcogenide layers are suitable for a wide range of solar cell application [3, 4 .

Bismuth chalcogenides $\left(\mathrm{Bi}_{2} X_{3}, X=\mathrm{S}, \mathrm{Se}, \mathrm{Te}\right)$ are semiconductor compounds that have gained atten-

\footnotetext{
* Corresponding author. Email: ingrida.ancutiene@ktu.lt
}

tion for use in photovoltaics, thermoelectric devices, photoconductive materials, and topological insulators [5-7]. $\mathrm{Bi}_{2} \mathrm{Se}_{3}$ is one of the widely studied material because of its suitable optical properties. Bismuth selenide is a narrow direct band gap semiconductor $\left(E_{g} \sim 0.3 \mathrm{eV}\right)$ and its tunable band gap is useful for solar cell applications [8, 9]. $\mathrm{Bi}_{2} \mathrm{Se}_{3}$ has attracted considerable attention due to its characteristic anisotropic layered structure as well as important applications in the field of optical recording systems and stain gauges [9, 10]. For bismuth based compound $\mathrm{CuBiSe}_{2}$ a direct band gap is in the range $1.1-1.5 \mathrm{eV}$, and it has been suggested as photovoltaic absorber material [11, 12]. This ternary semiconductor contains elements like $\mathrm{Cu}$ and $\mathrm{Bi}$ that are earth-abundant and nontoxic [3]. 
The synthesis of various metal selenides layers has been realized by many methods, such as chemical bath deposition [13-15], successive ionic layer adsorption and reaction [13, 16, 17], electrodeposition [12, 18], evaporation [10], etc. Mostly used approaches to synthesize metal selenides are chemical bath deposition (CBD) and successive ionic layer adsorption and reaction (SILAR) methods [2]. These methods are well known and commonly used for the preparation of thin films because of their low temperature requirement, low cost, suitability for large-scale deposition areas and ability to deposit films on different types of substrates. However, using the CBD method a precipitate forms in the bulk of solution, this wastage of materials is avoided in the SILAR method when thin films are obtained by immersing a substrate into separately placed cationic and anionic precursors and rinsing with water between each immersion [13].

In this paper we report on the formation of copper bismuth selenides layers on glass by the SILAR method. As the precursor of selenium we used solutions of selenopolythionate acids, $\mathrm{H}_{2} \mathrm{Se}_{n} \mathrm{~S}_{2} \mathrm{O}_{6}$. The layers formed were characterized using scanning electron microscopy coupled with energy dispersive X-ray spectroscopy (SEM-EDX) and X-ray diffraction (XRD) analysis in order to determine the morphology, chemical and phase composition of the obtained layers.

\section{EXPERIMENTAL}

Layers of copper and copper bismuth selenides on soda lime glass substrates with one side sandblasted were obtained. The substrates of $10 \times 10 \times 1 \mathrm{~mm}$ were first cleaned with a liquid soap and washed with distilled water, then they were cleaned ultrasonically in an acetone bath by using a Sonoswiss SW $3 \mathrm{H}$ cleaner for $10 \mathrm{~min}$ at $40^{\circ} \mathrm{C}$ using the sweep mode. The substrates were dried in air and used for layer deposition. The selenium layer was formed by submerging the glass substrate into a $0.4 \mathrm{~mol} / \mathrm{L}_{2} \mathrm{SeO}_{3}$ and $1 \mathrm{~mol} / \mathrm{L} \mathrm{NaHSO}_{3}$ 1:1 mixture for $3 \mathrm{~h}$ at $60^{\circ} \mathrm{C}$. Then, the sample was rinsed in distilled water and placed in a solution of $0.4 \mathrm{~mol} / \mathrm{L} \mathrm{CuSO}_{4}$ with an addition of $1 \%$ hydroquinone for $10 \mathrm{~min}$ at $60^{\circ} \mathrm{C}$. It is a mixture of univalent and divalent copper salts consisting of $0.34 \mathrm{~mol} / \mathrm{L} \mathrm{Cu}(\mathrm{II})$ and $0.06 \mathrm{~mol} / \mathrm{L} \mathrm{Cu}(\mathrm{I})$ salt [ 19$]$. The process of layer formation was repeated three times in order to achieve the suitable thickness. Later the substrates were rinsed with distilled water and submerged in a $0.1 \mathrm{~mol} / \mathrm{L} \mathrm{Bi}\left(\mathrm{NO}_{3}\right)_{3}$ solution with triethanolamine $(\mathrm{pH} \approx 9)$ for $20 \mathrm{~min}$ at $60^{\circ} \mathrm{C}$; the samples were rinsed in distilled water again and dried over $\mathrm{CaCl}_{2}$. Finally, the samples were annealed for $24 \mathrm{~h}$ in the inert nitrogen atmosphere at $100^{\circ} \mathrm{C}$.

For the characterization of the obtained layers the XRD analysis and SEM-EDX measurements were recorded. The XRD studies on a D8 Advance diffractometer (Bruker AXS, Germany) operating at $40 \mathrm{k}$ tube voltage and $40 \mathrm{~mA}$ tube current were performed. Diffraction patterns were recorded in Bragg-Brentano geometry, using a fast counting 1-dimensional detector Bruker LynxEye based on silicon strip technology. The X-ray beam was filtered with a Ni $0.02 \mathrm{~mm}$ filter to suppress $\mathrm{Cu}-\mathrm{k}$ alfa $\beta$-radiation and the specimens were scanned over the range $2 \theta=3-70^{\circ}$ at a scanning speed of $6^{\circ} 1 / \mathrm{min}$ using a coupled two theta/theta scan type. The diffractometer is supplied together with the software package DIFFRAC.SUITE. $\mathrm{X}$-ray diffractograms of the deposited layers were processed using the software packages Search Match, ConvX, Xfit and Microsoft Office Excel. In order to study the morphology of the samples and the elemental composition of the obtained layers a scanning electron microscope Raith e-Line (Raith, Germany) equipped with an energy dispersive spectrometer Quantax 400 with a detector XFlash 3001 (Bruker AXS, Germany) was used.

All reagents used in the experiments were chemically and analytically pure commercial reagents. Selenous acid, $\mathrm{H}_{2} \mathrm{SeO}_{3}$ (99.999\% trace metals basis from Sigma-Aldrich), sodium hydrosulfite, $\mathrm{NaHSO}_{3}(\geq 99 \%$ from Sigma-Aldrich), crystalline copper sulphate pentahydrate, $\mathrm{CuSO}_{4} \cdot 5 \mathrm{H}_{2} \mathrm{O}$ (crystals and lumps, 99.999\% trace metals basis, from Sigma-Aldrich), hydroquinone, $\mathrm{C}_{6} \mathrm{H}_{4}(\mathrm{OH})_{2}$ (flakes, $\geq 99 \%$ ReagentPlus ${ }^{\oplus}$ from Sigma-Aldrich), bismuth(III) nitrate pentahydrate, $\mathrm{Bi}\left(\mathrm{NO}_{3}\right)_{3} \cdot 5 \mathrm{H}_{2} \mathrm{O}$ (reagent grade, 98\% from Sigma-Aldrich), triethanolamine, $\left(\mathrm{HOCH}_{2} \mathrm{CH}_{2}\right)_{3} \mathrm{~N} \quad(\geq 98 \%$ from Sigma-Aldrich) were used for the experiments. 


\section{RESULTS AND DISCUSSION}

It is known [20] that components of a selenous acid and sodium hydrosulfite mixture react with each other and diseleniumtetrathionate acid in a solution is formed:

$$
\begin{aligned}
& 2 \mathrm{H}_{2} \mathrm{SeO}_{3}+5 \mathrm{NaHSO}_{3} \rightarrow \mathrm{H}_{2} \mathrm{Se}_{2} \mathrm{~S}_{2} \mathrm{O}_{6}+ \\
& +2 \mathrm{Na}_{2} \mathrm{SO}_{4}+\mathrm{NaHSO}_{4}+3 \mathrm{H}_{2} \mathrm{O} .
\end{aligned}
$$

By heating diseleniumtetrathionate decomposes and releases elemental selenium, which is deposited on a glass substrate:

$$
\mathrm{Se}_{2} \mathrm{~S}_{2} \mathrm{O}_{6}^{2-} \rightarrow \mathrm{Se}+\mathrm{SeS}_{2} \mathrm{O}_{6}^{2-} \text {. }
$$

Seleniumtrithionate formed is not stable and decomposes:

$$
\mathrm{SeS}_{2} \mathrm{O}_{6}^{2-} \rightarrow \mathrm{Se}+\mathrm{SO}_{4}^{2-}+\mathrm{SO}_{2} \text {. }
$$

Copper selenides form during the heterogeneous oxidation-reduction reaction between elemental selenium on glass and $\mathrm{Cu}^{+}$in the copper salt solution:

$$
\mathrm{Se}+2 x \mathrm{Cu}^{+} \rightarrow \mathrm{Cu}_{x} \mathrm{Se}+x \mathrm{Cu}^{2+} \text {. }
$$

In order to prepare bismuth selenide layers, the $\mathrm{Cu}_{x}$ Se layers on glass are chemically converted by a bismuth nitrate solution. Such a chemical process allows an exchange of copper ions by bismuth ions and may be described by

$$
\begin{aligned}
& 3 \mathrm{CuSe}+3 \mathrm{Cu}_{2} \mathrm{Se}+4 \mathrm{Bi}^{3+} \rightarrow \\
& 2 \mathrm{Bi}_{2} \mathrm{Se}_{3}+3 \mathrm{Cu}^{2+}+6 \mathrm{Cu}^{+} .
\end{aligned}
$$

An exchange of ions is possible because the solubility product for $\mathrm{Bi}_{2} \mathrm{Se}_{3}$ is $8.9 \times 10^{-105}$, whereas for $\mathrm{CuSe}$ and $\mathrm{Cu}_{2} \mathrm{Se}$ the solubility products are $1.4 \times 10^{-36}$ and $1.1 \times 10^{-51}$, respectively [21].

Surface properties of the obtained layers were studied by recording scanning electron microscope micrographs. Figures 1 and 2 display the surface microstructures of the specimens that contained selenium, copper and bismuth selenides. The morphology of the copper selenide layer without bismuth ion adding (Fig. 1) appeared to be non-uniform with a dendritic structure. It is clearly seen that this layer forms after the aggregation of irregular-shaped particles. The addition of bismuth ions drastically changed the microstructure of the layer (Fig. 2). The surface of the converted layer is denser, smoother and covered by closely spaced spherical shaped grains. The size of spherical grains was $1-8 \mu \mathrm{m}$.

EDX spectroscopy was used to determine the elemental composition of the formed and converted layers. The EDX spectrum of the obtained copper selenide layer shows the presence of $\mathrm{Cu}$, $\mathrm{Se}$ and Si peaks (Fig. 11). One of selenium peaks is especially intense. This indicates that the layer contains an excess of elemental selenium. The existence of silicon is believed to have appeared from a glass substrate. The EDX results confirm the presence of bismuth, selenium and copper in the converted sample (Fig. 2). A comparison of the EDX spectroscopy data of those layers shows the reduction of copper and selenium in the converted layer (Table). That means that copper ions are released from the copper selenide layer during reaction with bismuth (III) ions, as shown in Eq. (5), and the amount of copper in the converted layer decreased. The results indicate that the converted layer is rich in copper (25.01 at.\%) and poor in bismuth (5.25 at.\%). This could be due to the fact that a 3-cycle copper selenide layer was used for chemical conversion by a bismuth salt solution.

The phase composition of a layer was established by comparing its X-ray diffraction pattern with those of known minerals, the area of $2 \Theta \geq 20.0^{\circ}$ was investigated in more detail. The results of the phase analysis of the samples with a formed three-cycle copper selenide layer and a converted layer are summarized in Fig. 3 . After treating of the selenium layer in a $\mathrm{Cu}(\mathrm{II} / \mathrm{I})$ salt solution (pattern a), the peaks at $2 \Theta=26.6$, $28.0,31.1$ and $50.0^{\circ}$ attributable to hexagonal klockmanite $\mathrm{Cu}_{0.87}$ Se (JCPDS: 83-1814) and the peak at $2 \Theta=45.5^{\circ}$ attributable to $\beta$-copper selenide CuSe (JCPDS: 27-184) are observed. It can be seen that the klockmanite phase predominates in the selenide layer. After treating the copper selenide layer with a bismuth(III) salt solution (pattern b) only the peaks of copper selenide in the converted layer were detected. This means that bismuth selenide can be in the amorphous phase. 


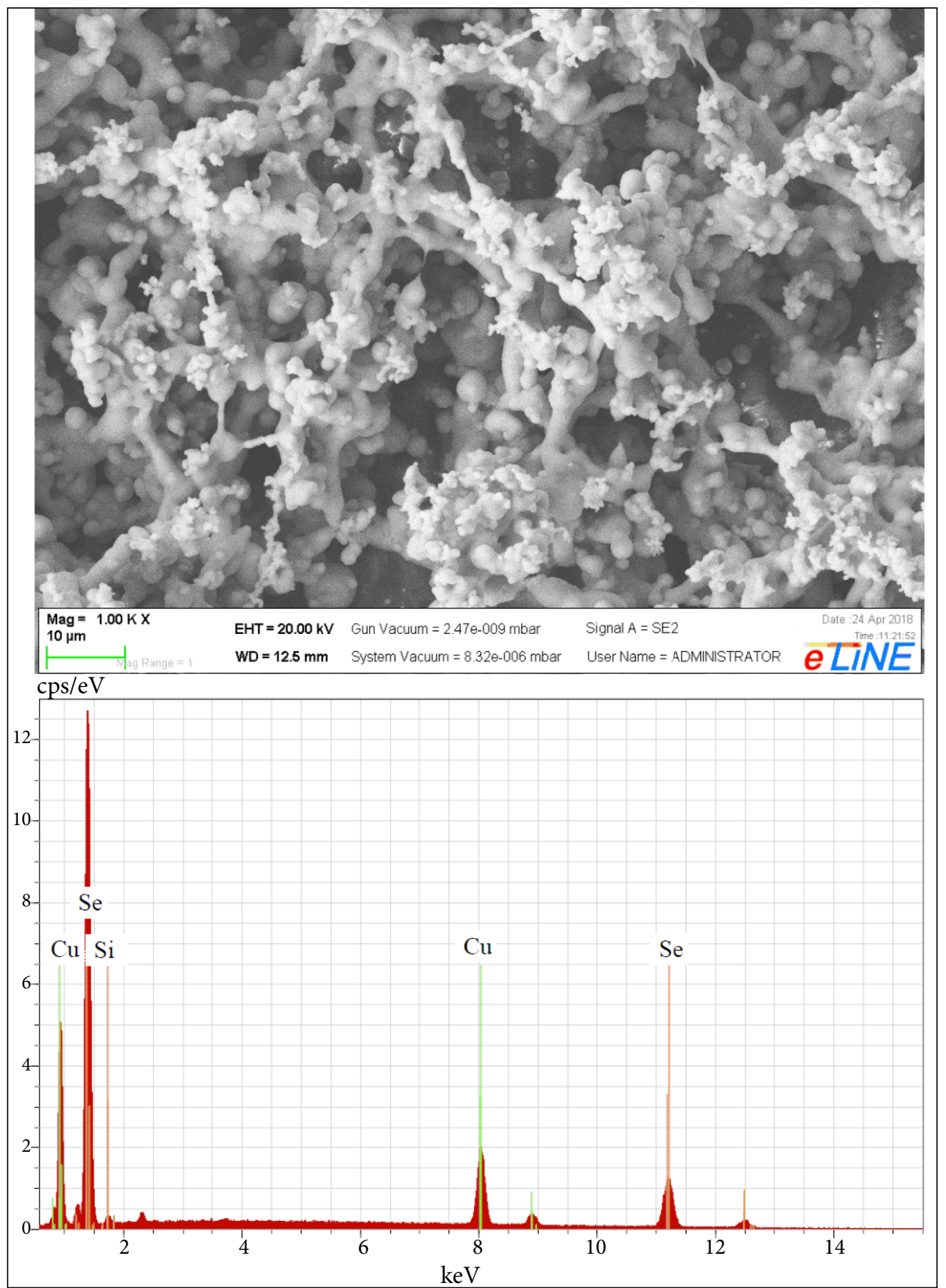

Fig. 1. The SEM micrograph at $1000 \times$ magnification and the EDX spectrum of the obtained copper selenide layer on glass

The results of this research showed that annealing was needed to obtain a bismuth based compound. As shown in Fig. 3 pattern c, the peaks of the copper bismuth selenide $\mathrm{Cu}_{1.6} \mathrm{Bi}_{4.8} \mathrm{Se}_{8}$ (JCPDS: 80-1592) phase at $2 \Theta=23.5,43.7$ and $51.6^{\circ}$ after annealing the converted layer in the inert (nitrogen) atmosphere were observed. It is possible that copper selenide reacts with bismuth cations by the following equation:
$8 \mathrm{CuSe}+4 \mathrm{Bi}^{3+} \rightarrow \mathrm{Cu}_{2} \mathrm{Bi}_{4} \mathrm{Se}_{8}+6 \mathrm{Cu}^{2+}$.

Also, copper bismuth selenide can be obtained by the solid-state reaction proceeded at $100^{\circ} \mathrm{C}$ when copper selenide reacts with bismuth selenide via

$$
2 \mathrm{CuSe}+2 \mathrm{Bi}_{2} \mathrm{Se}_{3} \rightarrow \mathrm{Cu}_{2} \mathrm{Bi}_{4} \mathrm{Se}_{8} .
$$




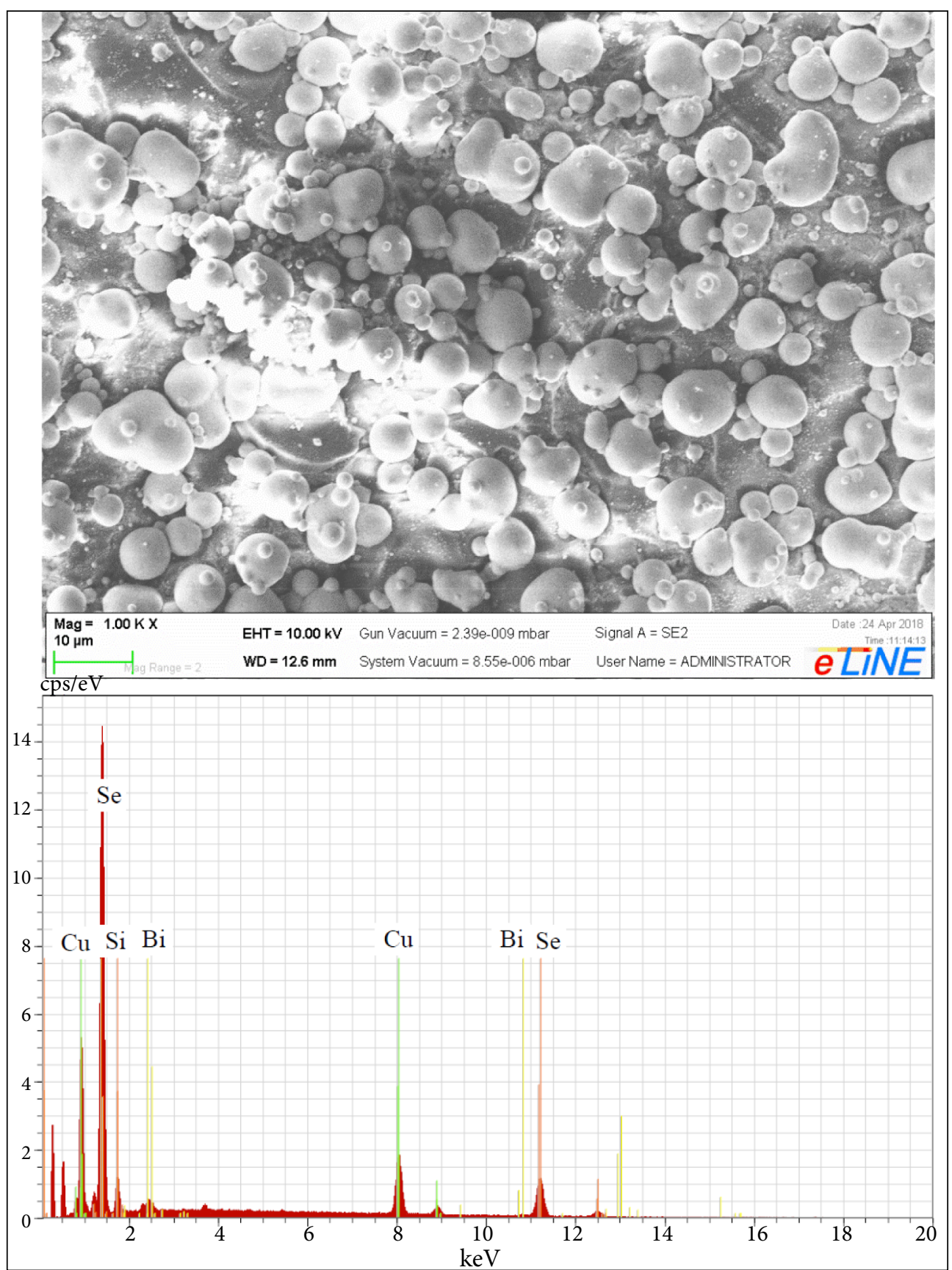

Fig. 2. The SEM micrograph at $1000 \times$ magnification and the EDX spectrum of the obtained copper bismuth selenide layer on glass

Ta ble. The elemental composition of the layers by EDX (excluded Si)

\begin{tabular}{c|c|c|c}
\hline Element & $\begin{array}{c}\text { Se (at.\%) } \\
\text { K-series }\end{array}$ & $\begin{array}{c}\text { Cu (at.\%) } \\
\text { K-series }\end{array}$ & $\begin{array}{c}\text { Bi (at.\%) } \\
\text { L-series }\end{array}$ \\
\hline Copper selenide & $71.80 \pm 3.0$ & $27.55 \pm 0.9$ & - \\
\hline Converted & $63.87 \pm 2.8$ & $25.01 \pm 0.8$ & $5.25 \pm 0.7$ \\
\hline
\end{tabular}

The annealing process promotes the appearance of the hexagonal selenium Se (JCPDS: 73-465) phase with a very intensive peak at $2 \Theta=29.7^{\circ}$. This indicates that in these samples selenium and bismuth selenide or copper bismuth selenide were in the amorphous phase, and after annealing they changed from an amorphous to a crystal phase. The XRD diffraction pattern of 


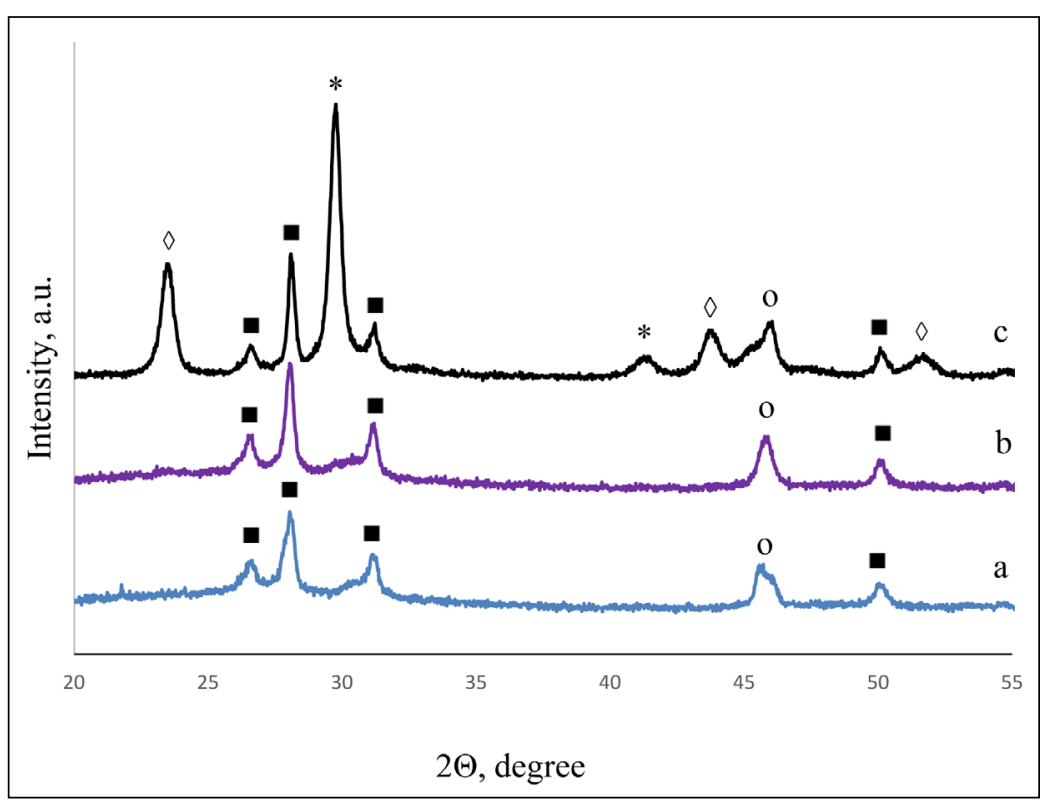

Fig. 3. XRD patterns of the obtained layers on glass: (a) the formed three-cycle layer of $\mathrm{Cu}_{\mathrm{x}} \mathrm{Se},(\mathrm{b})$ the converted layer, $(\mathrm{c})$ the annealed converted layer. Peaks were identified and assigned as follows: $(\diamond) \mathrm{Cu}_{1.6} \mathrm{Bi}_{4.8} \mathrm{Se}_{8}(80-1592)$, copper bismuth selenide; ( $\left.\mathbf{\square}\right) \mathrm{Cu}_{0.87} \mathrm{Se}$ (831814), hexagonal klockmanite, ( $)$ CuSe (27-184), $\beta$-copper selenide and $\left({ }^{*}\right)$ Se (73-465), hexagonal selenium.

the chemically converted layer showed predomination of the phases of elemental selenium and copper selenides. Thus, the formed copper selenide layer was not fully modified.

\section{CONCLUSIONS}

In the study we present the formation of a copper bismuth selenide layer by the chemical conversion method via the reaction between the copper selenide layer on a glass substrate and a bismuth(III) salt solution. The SEM images showed layers with a non-homogeneous morphology. The three-cycle copper selenide layer was non-uniform and consisted of dendrites and particulated agglomerates. The surface of the chemically converted layer was denser and smoother with closely spaced spherical shaped grains. The EDX results revealed that the converted samples were rich in copper and poor in bismuth. The XRD data showed that copper selenide peaks were most dominant with the hexagonal klockmannite phase. Hexagonal selenium and copper bismuth selenide phases after annealing in the inert nitrogen atmosphere were observed in the converted layer. Copper bismuth selenide was formed by ion-exchange or solid state reactions.
Received 21 November 2018 Accepted 30 November 2018

\section{References}

1. S. Kumar, Z. H. Khan, M. A. M. Khan, M. Husain, Curr. Appl. Phys., 5, 561 (2005).

2. R. S. Mane, C. D. Lokhande, Mater. Chem. Phys., 65, 1 (2000).

3. N. Suriyawong, B. Aragaw, J.-B. Shi, M.-W. Lee, J. Colloid Interface Sci., 473, 60 (2016).

4. K. Takei, T. Maeda, T. Wada, Thin Solid Films, 582, 263 (2015).

5. K. Tezuka, S. Kase, Y. J. Shan, J. Asian Ceram. Soc., 2, 366 (2014).

6. A. K. Rath, M. Bernechea, L. Martinez, G. Konstantos, Adv. Mater., 23, 3712 (2011).

7. G. Konstantos, L. Levina, J. Tang, E. H. Sargent, Nano Lett., 8, 4002 (2008).

8. N. D. Desai, K. V. Khot, V. B. Ghanwat, S. D. Kharade, P. N. Bhosale, J. Coloid Interface Sci., 514, 250 (2018).

9. P. Hu, Y. Cao, D. Jia, L. Wang, Mater. Lett., 64, 493 (2010).

10. R. Indirajith, M. Rajalakshmi, R. Gopalakrishnan, K. Ramamurthi, Superlattices Microstruct., 91, 165 (2016).

11. M. Kumar, C. Persson, Energy Procedia, 44, 176 (2014).

12. J. Li, L. Jiang, B. Wang, et al., Electrochim. Acta, 87, 153 (2013). 
13. S. M. Pawar, B. S. Pawar, J. H. Kim, O.-S. Joo, C. D. Lokhande, Curr. Appl. Phys., 11, 117 (2011).

14. V. M. Garcia, M. T. Nair, P. K. Nair, R. A. Zingaro, Semicond. Sci. Technol., 12, 645 (1997).

15. R. B. Kale, S. Y. Lu, J. Alloys Compd., 640, 504 (2015).

16. I. A. Ji, H. M. Choi, J. H. Bang, Mater. Lett., 123, 51 (2014).

17. A. Ivanauskas, R. Ivanauskas, I. Ancutienè, Chalcogenide Lett., 13, 373 (2016).

18. M. F. Gromboni, L. H. Mascaro, J. Electroanal. Chem., 780, 360 (2016).

19. I. Ancutienè, V. Janickis, S. Grevys, Chemistry, 2, 3 (1997).

20. J. Šukytè, A. Ivanauskas, I. Ancutienè, Chalcogenide Lett., 12, 569 (2015).

21. R. A. Ligin, L. L. Andrejeva, V. A. Molochko. Reference Book of Inorganic Chemistry, Moscow, Khimiya (1987).
Viktorija Osipovaitė, Ingrida Ancutienė

\section{VARIO BISMUTO SELENIDU SLUOKSNIŲ, GAUTŲ CHEMINIO PAKEITIMO BŪDU, MORFOLOGIJA IR SUDĖTIS}

Santrauka

Pateiktas paprastas būdas vario bismuto selenidu sluoksniams gauti cheminio pakeitimo būdu, vykstant reakcijoms tarp vario selenidu sluoksniu ant stiklo ir bismuto nitrato tirpalo. SEM nuotraukose matyti netolygus trijų apdorojimo ciklų vario selenidų sluoksnis, sudarytas iš dendritų ir aglomeratų, kuris tampa tankesnis ir lygesnis, su apvalios formos dalelemis, kai jis paveikiamas bismuto (III) jonais. EDX analizè parodé, kad chemiškai pakeistuose sluoksniuose yra nedidelis kiekis bismuto ir daug vario. RSDA rezultatai atskleide, kad sluoksniuose vyrauja vario selenidai, ir tik iškaitinus sluoksnị inertinèje azoto atmosferoje difraktogramoje stebimos vario bismuto selenido ir elementinio seleno fazių smailès. Vario bismuto selenidas susidaro vykstant jonų mainų reakcijoms ar kietafazei reakcijai. 
